stems, and branches of injured or broken trees, in the form of resin, which on evaporation became thickened, and finally assumed the form of succinite or some similar substance. For the most part the fossil resin has been derived from the stems and roots of coniferous trees of the genus Pinuts. In addition to the exceptionally well-preserved tissues of coniferous trees, the Baltic amber has yielded remarkable specimens of monocotyledonous and dicotyledonous flowers. Some of the most striking examples were illustrated by means of the excellent coloured plates from Dr. Conwentz' monographs on the Baltic amber.

The Wealden flora of England, by A. C. Seward. Mr. A. C. Seward, after referring to the various species described by Mantell, Carruthers, Starkie Gardner, and others, from the Wealden strata of England, briefly described a large number of plants from the British Museum collection. During the last few years Mr. Rufford, of Hastings, has obtained an extremely valuable and rich collection of plants from Ecclesbourne, Fairlight, and other localities; and these have now become the property of the nation. The following species are at present known from the Wealden of England ; some of these have already been figured in the first volume of the catalogue of the Wealden flora, and the remainder are dealt with in the forthcoming second volume :-Algites valdensis, sp. nov., A. catenelloides, sp. nov., Chara Knowltoni, sp. nov., Marihantites Zeilleri, sp. nov., Equisetites Lyclli, Mant., E. Burhardti, Dunk., E. Yokoyami, sp. nov., Onychiopsis Mantelli (Brong.), O. elongata (Geyl.), Acrostichopteris Kuffordi, sp. nov., Matonidium Göpperti (Ett.), Protopteris Witteana, Schenk., Ruffordia Gopperti (Dunk.), Cladophlebis longipennis, sp. nov., C. Albertsiï(Dunk.), C. Browniana (Dunk.), C. Dunkeri (Schimp.), Sphenopteris Fontainei, sp. nov., S. Fittoni, sp. nov., Weichselia Mantelli (Brong.), Teniopteris Beyrichii (Schenk.), T. Dawsoni, sp. nov., Sagenopteris Mantelli (Dunk.), S. acutifolia, sp. nov., Microdictyon Dunkeri, Schenk., Dictyophyllum Römeri, Schenk, Leckenbya valdensis, gen. et sp. nov., Tempskya Sihimperi, Cord., Cycadites Römeri, Schenk., C. Saporte, sp. nov., Dioonites Dunkerianus (Göpp.), D. Bronsniarti (Mant.), Nilssonia Schanmburgensis (Dunk.), Otozamites Klipsteinii, (Dunk.), O. Goppertianus (Dunk.), Zamites Buihianus (Ett.), Zamites Carruthersi, sp. nov., Anomozamites Lyellianus (Dunk.), Cycadolepis, Carpolithes, Androstrobus Nathorsti, sp. nov., Conites elegans (Carr.), C. armatus, sp. nov., Bucklandia anomala (Stokes and Webb), Fittonia l'uffordi, sp. nov., Bennettites Saxbyanus, Brown, B. Gibsonianus, Carr., B. (Willianusonia) Carnthersi, sp. nov., Yatesia Morrisii, Carr., Withamia Saporta, gen. et sp. nov., Becklesia anomala, gen. et sp. nov., Dichopteris, sp., Sphenolepidium Kurrianum (Schenk.), S. Stcrnbergiamum (Dunk.), Pagiophyllum crassifolium (Schenk.), Brachyphyllum obesum, Heer, B. spinosum, sp. nov., Pinites Solmsi, sp, nov., P. Dunkeri, Carr, P. Mantelli, Carr, $P$. patcns, Carr., P. Carruthersi, Gard., \&c.

\section{SCIENCE IN THE MAGAZINES.}

THE personal reminiscences of Iruxley, contributed by Mr. George W. Smalley to the current number of Scribner, will bring up pleasant memories to those who were honoured by the friendship of the departed naturalist, and they form an affectionate tribute " to the memory of one of the truest men who ever lived, one of the manliest, and in all points the noblest." There is in the article so much real testimony to Huxley's greatness, that every student of science will appreciate it. "The emancipation of thought," truly says Mr. Smalley, "that is Huxley"s legacy to his century - that was his continual lesson of intellectual honesty." Against those who criticised Huxley's philosophical learning we quote these words : "In truth he was a very expert metaphysician, with an extraordinary knowledge of the literature of metaphysics and philosophy. . . Huxley was a student, and more than a student, of Descartes. He has written the best short book in existence on Hume. He was a pupil of Aristotle, and therefore not a Platonist. Hobbes taught him much ; Berkeley was to him a great thinker; Locke, Butler, and the short list of really great names in English philosophy were all his familiars, while among the great Germans there was, I think, none whom he did not know well-Kant, Hegel, Fichte, and all that illustrious line, not excepting Schopenhauer." But Huxley's claim to recognition as one of the world's foremost thinkers, now unhappily lost to us, need not be enlarged upon here. "He will be remembered as the great physiologist, the great student, the great controversialist, the great thinker and writer. That he will be remembered need not be doubted. The world, it may still be said, does not willingly let die the memory of those who have made it a better world to live in, whose lives as well as whose teachings have been lessons of devotion, of high aims, of wide accomplishments, of honourable purpose; whose achievements are written imperishably in the annals of their own time. Huxley was one of these, and his monument in his life's endeavour. There will be no need to inscribe Right Honourable upon his tomb. The name he bore through life will serve both for epitaph and eulogy."

There are other articles in Scribner which will interest the readers of NATURE. One of these is a fully illustrated description of the new Chicago University, by Mr. Herrick. Magnificent buildings have been erected, and an endowment of over $£ \mathrm{I}, 200,000$ has been bestowed in the short period of four years, as well as a generous annual budget for current expenses. This phenomenal generosity, together with the fact that there will be no question of adequate support as fresh opportunities for development occur, point to the University of Chicago as a great and growing centre of intellectual activity. In some respects the system of the University resembles that of our older Universities, but others--such as the emphasis placed upon the doctor's degree, investigation, research, \&c., and the activity of the graduate schools-point to the German University as the prevailing influence. It will astonish many of our schoolmen to know that " the graduates in residence this year-in all over three hundred-form more than one-third of the entire body of students, a larger number than at any other American University. This preponderance of graduate students has been brought about by several reasons : the emphasis placed upon the advanced courses under the leadership of such heads of departments as Profs. Dewey, Hale, von Holst, Laughlin, Michelson and Nef, not to mention others; the special privileges and distinctions granted to graduates (for example, in many departments only graduate students are allowed in the special departmental laboratories, the $£ 6000$ annually offered in fellowships and scholar. ships; and the equal privileges accorded to women. It is a truism that the most distinctive move in American college life of the last decade has been in the sudden interest in post-graduate study. But hitherto in Western institutions, whether college or so-called university, has had the means to provide liberally for advanced studies." It will be clear from this quotation, and more clear from a perusal of the article, that the University of Chicago is developing in the right directions towards scholarship and new knowledge. Chicago people seem to have the cause of higher education at heart, and they are devoting their best energies, as well as generous financial support, to the magnificent institution which has so quickly sprung into existence, and which has such a great future before it.

The third article of scientific interest in Scribner is of "Domesticated Birds," by Prof. N. S. Shaler, and is beauti fully illustrated.

The sixth of Mr. Herbert Spencer's papers on professional institutions, contributed to the Contemporary, deals with the evolution of men of science and philosophers, and will, therefore, be of exceptional interest to our readers. So far as the series has as yet gone, it has been shown that the institutions dealt with were probably derived from the priesthood. Whatever may be the opinion with regard to the connection between the medical profession and priestcraft, it will be generally conceded that astronomy received its first impulse from the exigencies of religious worship. Extracts given by Mr. Spencer from Rawlinson, Layard, and Maury show clearly how closely religion and science (especially astronomical science) were mingled by the Babylonians. With the Egyptians, too, there is abundant evidence to prove an intimate connection between their science and their religion; and the connection is established by the fact that " in every temple there was... an astro. nomer who had to observe the heavens." Astronomy was thus an outgrowth of religion, and the natural knowledge accumulated by the priests formed the beginnings of sciences in Egypt, Assyria, and India. The Greeks imported this knowledge; in other words, they obtained their early science in a slightly developed state. Of the indebtedness of the Greek philosophers to the Egyptian priests there is no doubt whatever, and Mr. Spencer clearly makes out that obligation. The development of Greek science, however, is only in a small measure ascribed to the priesthood, the advances being more of secular than of sacred origin. "During those centuries of darkness which

NO. I 354 , VOL. 52 ] 
followed the fall of the Roman Empire," says Mr. Spencer, "nothing to be called science existed. But when, along with gradual reorganisation, the re-genesis of science began, it began as in earlier instances among the cultured men-the priesthood." The man of science and the philosopher have gradually differentiated from the clerical class, one to deal with the concrete and the other to be concerned with abstract matters, and now the distinction between the two is tolerably definite. Simultaneously a subdivision of the body of scientific men has gone on, until we reach these days of minute specialisation. And finally, we have the combination of the units in such institutions as the Royal Society and British Association, and in the serial scientific publications which are general in their scope. In addition to the admirable article summarised in the foregoing, Mr. Spencer contributes to the Contemporary a brief note in reply to Prof. Weismann.

A suggestive paper, by Dr. A. R. Wallace, on "The Expressiveness of Speech," appears in the Fortnightly. The paper contains a number of interesting facts which point to mouth gesture as a factor in the origin of language. Here is Dr. Wallace's idea : "In our own language, and probably in all others a considerable number of the most familar words are so constructed as to proclaim their meaning more or less distinctly, sometime by means of imitative sounds, but also, in a large number of cases, by the shape or the movements of the various parts of the mouth used in pronouncing them, and by peculiarities in breath ing or in vocalisation, which may express a meaning quite independent of mere sound-imitation." Anthropologists and philologists should be interested in the many facts which Dr. Wallace has brought together in support of his view.

Limits of space prevent us from giving more than brief descriptions of the remaining articles of scientific interest in the magazines received. In Science Progress, Mr. F. H. Neville traces recent progress in the study of alloys; galvanotropism in tadpoles is described by Dr. A. Waller, F.R.S. ; the chromatophores of animals, by Mr. W. Garstang; the space relation of animals, by Dr. A. Eiloart; and the synthesis of proteids, by Prof. W. D. Halliburton, F.R.S. Chambers's Journal has short popular papers on "Horseless Carriages," "New Methods of Illumination," and "Cotton-Seed Oil." In GoodWords we notice an article on "Falconry," by Mr. R. B. Lodge, illustrated by two photographs from life-one showing a peregrine and partridge, and the other a goshawk and rabbit. The two plates are finely engraved, but we think their value would have been greater had they been photographic reproductions from the original negatives. The Humanitarian is distinguished by a psychical article entitled " Dynamic Thought," by Prof. W. F. Barrett ; and the National Review has a paper in which Selbornians will find pleasure, by the Hon. Mrs. R. Boyle. In addition to the magazines named in the foregoing, we have received the Sunday Magazine and Longman's.

\section{UNIVERSITY AND EDUCATIONAL INTELLIGENCE.}

CAMBRIDGE.-Five candidates, namely, R. A. Berry, G. Joyce, H. C. Sheringham, W. M. Tod, and B. N. Wale, have been successful in the recent examination in the science and art of agriculture, and have received the University diploma.

Mr. Charles Smith, Master of Sidney Sussex College, and author of several much-used mathematical text-books, was on October $I$ admitted to the office of Vice-Chancellor for the current academical year. The outgoing Vice-Chancellor, Mr. A. Austen Leigh, in his parting address to the Senate, referred in sympathetic terms to the loss sustained by the University in the death of Prof. Cayley and of Prof. Babington. He announced that the latter had bequeathed to the University his large and valuable collection of plants. A part of the address was devoted to a description of the difficulties, chiefly financial, which have attended the inception of the Sedgwick Memorial Museum of Geology. The satisfactory progress made with the extension of the Cavendish Laboratory, now approaching completion, was made a matter of congratulation.

Two scholarships in Natural Science, one of $£ 70$ and one of $£_{40}$ a year, will be competed for at Sidney Sussex College on December I2 to I4. Candidates are to make preliminary application to the tutor, Mr. G. M. Edwards.

NO. J 354 , VOL. 52]
The late Brof. Babington has left to the University his botanical library as well as his valuable collection of plants

Mr. H. F. Baker, of St. John's, and Mr. J. E. Edwards, of Sydney, have been appointed the Moderators, and Mr. R. A. Herman, of Trinity, and Mr. H. W. Richmond, of King's, the Examiners for the Mathematical Tripos of $\mathbf{I} 896$.

Dr. Glaisher has been appointed an Elector to the Isaac Newton Studentship in Astronomy.

A complete series of lectures for agricultural students, under the Cambridge and Counties Agricultural Education Scheme, has been arranged for three terms of the academical year. The syllabus is published in the Universily Reporter of October 8.

The first Entrance Scholarship in Natural Science, of the value of $£ 150$, into St. Thomas's Hospital Medical School has been awarded to Mr. Frank B. Skerrett; the second, of the value of £6o, being divided between Messrs. Walter B. Fry, George W. Hare, and Alfred B. Lindsey, bracketed equal. The Entrance Scholarship, value $£ 50$, for students from the Universities, has been awarded to Mr. Percy W. G. Sargent, St. John's College, Cambridge.

At Guy's Hospital, the Entrance Scholarship in Science, of the value of $\notin 150$, has been awarded to Mr. P. W. L. Camps, and the Second Entrance Scholarship in Science, of the value of $£ 60$, has been awarded to Mr. S. Hodgson.

THE Treasury has decided that the annual grant of which King's College, London, was deprived under the late Government may be restored to the college next year without any stipulation as regards tests.

\section{SCIENTIFIC SERIALS.}

American Meteorological Journal, September.-Synchronous or simultaneous geographical distribution of hourly wind velocities in the United States, by Dr. F. Waldo. This article is part of a memoir prepared for the U.S. Weather Bureau, and is supplementary to one which appeared in the Toumal for July (NATURE, p. 335). Charts are drawn for midnight and noon, for the extreme months of January and July, for about the centre of the United States, and afford a comprehensive view of the synchronous wind conditions and relations as regards the average velocities. This method of representation obviates the necessity of a lengthy text.- The origin and work of marine meteorology, by Lieut. W. H. Beehler, U.S.N. The author deals more particularly with the history and development of this service in the United States, from the appointment of Lieut. Maury as Superintendent of the U.S. Naval Observatory, in 1844, which led to the Maritime Conference held at Brussels in 1853. The numerous charts published by the Americart Office formed the basis of the useful wind charts subsequently issued by the Meteorological Department of the Board of Trade, during Admiral FitzRoy's lifetime, and which were widely distributed among seamen. The U.S. Hydrographic Office was established in 1866 , and in 1893 there were nearly 3000 observers co-operating with it. The outcome of this was the publication of the Pilot Chart of the North Atlantic Ocean, to which we have often had occasion to refer. About 4000 copies of this chart are distributed monthly, and among other things they have dome much towards bringing about the general recognition of the value of the use of oil to still the waves, by which numbers of vessels have been saved from total loss.

Bulletin of the American Mathematical Sotiety (vol. i. No. ro, July I895). - This closing number of vol. i. contains, in addition to the usual list of new pupblications and the index, a list of the published papers read before the Society during the year, together with the places of their publication.-Mr. J. M. Brooks gives a clear account of Lie's work on continuous groups $a$ propos of Scheffers' edition of the Vorlesungen uber Continuirliche Gruppen mit geometrischen und anderen Anwendungen. "The importance of the group idea itself has long been recog nised in its application to the theory of substitutions, and some continuous transformations, such as the pedal transformation, were in use before Lie's work, but were used without their connection with the group idea being discovered, and the discovery and the presentation of the results of it in a systematic form are due to Prof. Lie." Dr. Scheffers has aimed at giving in outline the general theory, and he indicates some lines in which it may be applied. - Prof. J. Harkness, in a review of the second volume 